\title{
Rolling bones: A preliminary study of micromammal abrasion on different initial taphonomic stages
}

\author{
Sara García-Morato, María Dolores Marin-Monfort, and Yolanda Fernández-Jalvo
}

\begin{abstract}
The identification of transport process is key to interpret the palaeoecology, the dating and the site formation. Apart from dispersal and size/shape selection, bone abrasion by water and sediment is an acquired taphonomic modification that makes transport recognizable in bone assemblages. Previous experiments with rodent bones used non-digested bones or emphasized abrasion on teeth to distinguish abrasion from digestion. Experiments with large mammals included different types of taphonomically modified bones. Following this procedure, two main aspects are here studied for the first time. On the one hand, we have focused on small mammal humeri and femora, which are also used to characterize digestion. We have also included different initial states or types of bones, such as digested, weathered or fossil bones to observe differences in abrasion behaviour that may help interpreting processes of water abrasion. On the other hand, we propose an easy test methodology to quantify the amount of surface loss. The resulting index to quantify surface loss shows light changes on bones abraded by clay and silts, in contrast to a more rapid and intense rounding of the salient angles by gravels. The latest yields a greater rounding and, therefore, surface loss, statistically significant. Cancellous tissues appear exposed after 72 hours of abrasion on proximal ends of femora and distal ends of humeri, mimicking corrosion produced by digestion. In this paper we describe key traits and quantify surface loss to distinguish between digestion and abrasion in postcrania, more specifically on proximal femora and distal humeri.
\end{abstract}

Sara García-Morato. Departamento de Geodinámica, Estratigrafía y Paleontología, Universidad Complutense de Madrid, C/ José Antonio Novais 12, 28040 Madrid, Spain and Museo Nacional de Ciencias Naturales-CSIC, C/ José Gutiérrez Abascal 2, 28006, Madrid, Spain. saragarciamlm@gmail.com María Dolores Marin-Monfort. Departamento de Paleobiología, Museo Nacional de Ciencias NaturalesCSIC, C/ José Gutiérrez Abascal 2, 28006, Madrid, Spain. doresmarinmonfort@gmail.com Yolanda Fernández-Jalvo. Departamento de Paleobiología , Museo Nacional de Ciencias Naturales-CSIC, C/ José Gutiérrez Abascal 2, 28006, Madrid, Spain. yfj@mncn.csic.es

García-Morato, Sara, Marin-Monfort, María Dolores, and Fernández-Jalvo, Yolanda. 2019. Rolling bones: A preliminary study of micromammal abrasion on different initial taphonomic stages. Palaeontologia Electronica 22.2.pvc-2 1-16. https://doi.org/10.26879/ 974 palaeo-electronica.org/content/pvc-2 
Keywords: Taphonomy, small mammals, long bone abrasion, water transport, rounding-digestion mimicking

Submission: 27 February 2019. Acceptance: 2 August 2019.

\section{INTRODUCTION}

Past environments have been traditionally interpreted using fossil faunas preserved at the site of study, but faunas in a fossil site may have been influenced by processes causing mixtures of fossils (Fernández-López, 1984, 1985, 1991, 1995, 2000) from different localities (re-sedimentation) and/or from different ages (reworking).

Palaeoecological and biochronological interpretations of a fossil site depend on taphonomic analyses to obtain more reliable interpretations (Efremov, 1940). In that sense, small mammals have a special importance as they are good palaeoecological indicators. Compared to large mammals, small mammals have well defined habitats, and their richness is highly correlated with the environment in which they inhabit (Andrews, 1990; Andrews and O'Brien, 2000, 2010). Predation is the main aspect that causes biotic transport of individuals from their original habitats to predator's habitats, and identification of predation traits have been extensively studied (e.g., Andrews, 1990; Fernández-Jalvo, 1995; Stoetzel et al., 2011; Fernández-Jalvo et al., 2016). Post- depositional taphonomic events caused by abiotic agents, such as water stream transport, may lead to mixtures in space and also in time, causing potential mistakes in palaeoecological and chrono-biostratigraphic interpretations. Taphonomy may then provide the information to distinguish and characterize potential mixtures of fossil assemblages to accurate interpretations of past ecosystems and evolutionary trends along time.

Water transport effects have been analysed by several authors (Voorhies, 1969; Dodson, 1973; Wolff, 1973; Behrensmeyer, 1975; Korth, 1979; Andrews and Ersoy, 1990; Evans, 2014), and bone abrasion is one of the principal consequences that makes water transport recognizable in bone assemblages together with anatomical distribution and skeletal representation (Voorhies, 1969). Water abrasion produces rounding and polishing that increases with sediment size and time of exposure (Korth, 1979), and it also depends to a large extent on the initial state of the bone being modified, i.e., fossil, weathered, dry and fresh bones
(Fernández-Jalvo and Andrews, 2003, 2016; Thompson et al., 2011).

Small mammal assemblages may appear in some sites associated to water streams, from caves (Laudet et al., 1997 in Pech Crabit, a karst deposit with subterranean water circulation in the galleries) or near fluvial channels (Tomassini and Montalvo, 2013; García-Morato et al., 2018). Therefore, evaluation of the effects of abrasion in small mammal bones is necessary. Previous works have been done by Andrews (1995), FernándezJalvo and Andrews (2003) and Fernández-Jalvo et al. (2014).

Experiments done by Fernández-Jalvo and Andrews (2003) tested the effects of abrasion produced by different sediment sizes on various bone types of large mammal bone fragments (i.e., fresh bones, dry bones, stage 4 of weathering and fossils). These authors also included several elements of rodent bones from barn owl (Tyto alba) pellets showing no signs of digestion. Similarly, Fernández-Jalvo et al. (2014) included small mammal bones selecting non-digested bones and teeth coming from captive barn owl pellets. These authors made more emphases on the dental elements to distinguish between the effects produced by digestion and by abrasion. However, it is frequent to observe in palaeontological or archaeological sites the presence of subsequent taphonomic modifications affecting bone surfaces. Most especially, fossil sites are primarily produced by predators (piling pellets or scats), and these modifications on their prey bones may be superimposed by other post-predation modifications and fossilization processes. Therefore, in small mammals, digestion is the most common taphonomic modification observed as a result of predation (Raczynski and Ruprecht, 1974; Mellet, 1974; Mayhew, 1977; Andrews, 1990; Fernández-Jalvo and Andrews, 1992; Lloveras et al., 2014; Fernández-Jalvo et al., 2016). Other postdepositional (pre-burial) modifications can subsequently affect the prey bones (e.g., trampling, weathering, compaction, soil corrosion...), as well as fossil-diagenetic modifications. Hence, distinguishing traits of each of the taphonomic processes that may have been involved is important when characterizing the influence of each taphonomic agent precisely to 
interpret in detail the palaeoecology, the age, the site formation and, in summary, the origin of the fossil accumulation.

In this study, apart from bone remains abraded by two different grain sizes of sediments (gravels and clay + silts), we have also included different types of bones i.e. digested, weathered and weathered + digested plus fossil bones (both digested and non-digested). Comparison between initial and final stages allows us to obtain further information on abrasion processes as shown in large mammal bones by Fernández-Jalvo et al. (2003), and in small mammals in this paper. This is, therefore, the first time that abrasion effects are analysed in detail on small mammal postcranial elements (namely femora and humeri) with different initial states affected by different taphonomic modifications. This experimental study allows us to obtain key traits to distinguish each taphonomic agent. In addition, we have applied in this paper an easy test methodology that provides quantitative criteria to analyse the effects of abrasion on bone surfaces by comparing pictures before and after the experiment to obtain an index of surface loss that may also help to identify abrasion in fossil sites and can be applied to both large and small mammal bone remains.

\section{MATERIAL AND METHODS}

Fossil assemblages of small mammal remains are usually accumulated as a consequence of predation, so even if bones appear physically nonmodified, they always have passed through the digestive system of a predator. With this in mind, the materials used in this experiment come from pellets and scats of different avian and mammalian predators (Table 1 ). The effects produced by abra- sion were tested on small mammal femora and humeri, with articular ends fused, because the taphonomic methodology (Andrews, 1990) takes these elements to evaluate the effects of digestion process. Most elements selected have similar size and completeness to reduce potential irregular results caused by inherent traits of the experimental sample. Main observations have been done on the distal part of the humeri and the proximal end of the femora in order to analyse how abrasion may modify previous taphonomic traits on these areas and how this can affect the shape of the bones depending on their initial taphonomic modification state. In this work we have selected: nonmodified, digested, weathered, weathered + digested bones, plus fossil bones, both nondigested and digested remains (Table 1). For this experiment, "non-modified" bones are referred to modern bones in which digestion traits are not observable.

Our experiment has included different types of small mammal humeri and femora from different predators' droppings. Therefore, even the nonmodified bones come from pellets of barn owls (Tyto alba), which have been kept in captivity and fed upon rodents every day. Tyto alba is the predator that causes the lowest grades of digestion in small mammal bones (Andrews, 1990), and a regular feeding makes intensity of digestion even milder than wild Tyto alba could produce on their prey in the nature. We have avoided bones from trapped mice to prevent preparation processes (e.g., boiling or mechanical procedures to remove the meat) that may potentially affect the bone surface (Fernández-Jalvo and Marin-Monfort, 2008) and weaken or alter the mechanical response of bones to abrasion. Completeness has been prioritized when selecting the sample for abrasion, also

TABLE 1. Bones taphonomically modified used for this study with the corresponding geographical area, predator involved and taxonomic group. Most of the rodents from European wildcat belongs to Muridae (Piñeiro and Barja, 2011) and fossil remains mostly belongs to Arvicolidae (Sesé and Villa, 2008; Williams et al., 2018). Taxonomic studies are not published for the remains of the captive barn owls and genet. As we are using postcranial remains, the identification to the level of species is difficult to obtain. * "Non-modified" bones were previously analysed to select those bones that had no signs of digestion.

\begin{tabular}{llll}
\hline \multicolumn{1}{c}{ Alteration } & \multicolumn{1}{c}{$\begin{array}{c}\text { Geographic } \\
\text { origin }\end{array}$} & \multicolumn{1}{c}{ Predator } & \multicolumn{1}{c}{ Taxonomic group } \\
\hline Non-modified & Spain & Captive barn owls (Tyto alba) & Rodentia \\
Weathered & Tanzania & Genet (Genetta genetta) & Rodentia/Eulipotyphla \\
Digested & Spain & European wildcat (Felis silvestris) & Rodentia \\
Weathered + digested & Tanzania & Genet (Genetta genetta) & Rodentia/Eulipotyphla \\
Non-digested fossils & France & Spotted hyena (Crocuta crocuta) & Rodentia \\
Digested fossils & France & Spotted hyena (Crocuta crocuta) & Rodentia \\
\hline
\end{tabular}


specimens bearing the proximal femur and the distal humerus fused. This may have influenced in the fact that 'digested' elements, either weathered or fossil, display mostly a light degree of digestion (Andrews, 1990 classification) even if they were eaten by mammalian carnivores. Other authors have reported the presence of non-digested or lightly digested remains in genet scats (Andrews and Evans, 1983; Matthews, 2006), and we have observed this in hyena coprolites (Williams et al., 2018) and wildcat scats (Marin-Monfort et al., in prep.) Digestion is more effective in broken than complete skeletal elements as described by Fernández-Jalvo and Andrews (2016): Breakage before digestion increases the effects of digestion, allowing digestive juices to penetrate into medullary cavities and increasing bone areas exposed to gastric acids. (p. 239). Although the experimental material has only got mild digestion, we may observe how abrasion affects digested bones.

Weathered bones of small mammals are difficult to obtain, as they quickly become buried (Andrews, 1990). We have found bones affected by weathering (physical effects caused by sun, wind, humidity and temperature changes) in a genet latrine exposed in the savanna near Olduvai (Tanzania) for several months. These remains show a weathering stage 1-2 (sensu Andrews, 1990): slight splitting of bone surface. Apart from trampling caused by the genet visiting the latrine, weathering also increases fragility by cracks and splits on the bone surface. Consequently, weathered elements from the genet latrine included in the experiments (with proximal and distal epiphyses attached to the bone metaphyses) could not always be possible to be complete.

Fossil bones (both digested and non-digested specimens) come from the French Late Pleistocene site of Bois Roche cave (Williams et al., 2018) dated to about 70 ka (MIS 4). These fossils have been used as another type or state of bone following the procedure of Fernández-Jalvo and Andrews (2003) in large mammals. Experiments using fossil long bones will allow us to analyse and quantify the effects of water abrasion on fossils to obtain criteria to distinguish potential reworking processes.

Postcranial elements are not the best skeletal element to taxonomically identify the specimen. Nonetheless, we may confirm through dental traits of these prey samples, that both fossil and modern European assemblages are rodents (arvicolids and/or murids), and African assemblages (weath- ered) contain mainly murids, but also some soricids have been identified (see Table 1).

The effects of abrasion caused by water and sediment were simulated with a stone polishing tumbler (KT-250 model) at the Laboratory of Experimental Taphonomy housed at the Museo Nacional de Ciencias Naturales (Madrid, Spain). Sediments used consist of gravels ( $>2 \mathrm{~mm}$ ) and clay + silts $(<125-<0.63 \mu \mathrm{m})$. The experiment was carried out in a first try including only non-modified, digested, weathered and weathered + digested specimens. A second experiment to corroborate the results obtained includes these specimens and fossil bones, both digested and non-digested.

For each group of taphonomic modifications we introduced four skeletal elements (two femora and two humeri) in containers with the sediment (gravel or clay and silt) and equal proportion of water (70 cc 3 of water and $70 \mathrm{cc}^{3}$ of sediment). The total sample observed taking into account the two experiments consists of 64 modern bones and 16 fossil bones. The tumbler $(21 \mathrm{~cm}$ of diameter) moves with a constant speed, which produces 30 revolutions per minute (r.p.m.). Observations were done after 24, 72, 192 and 360 hours, following the protocol of previous work from Fernández-Jalvo and Andrews (2003) (Figure 1). Most figures here show the initial and the final stages, although measurements, data and pictures were also taken in detail at each observation period (after 72 and 192 hours).

Photographs were taken under a binocular light microscope motorized in Z (Leica M205A) with a high resolution digital camera (Leica DFC450). Experimental bones were always photographed at the same side during the experiment to prevent errors caused by the position. We are working with photographs, and the small sample size only allows $2 \mathrm{D}$ analyses of the images. The distal humeri and the proximal femora were prioritized, because these ends are frequently analysed to evaluate digestion modification, but also extended to the whole skeletal element to obtain criteria to distinguish between these taphonomic modifications. Some specimens were selected and analysed at an environmental scanning electron microscope (SEM FEI-INSPECT low vacuum) located at the Museo Nacional de Ciencias Naturales (Madrid, Spain).

One of the effects caused by abrasion is the rounding of the surface and salient angles on the element affected (e.g., Korth, 1979; Behrensmeyer, 1988; Andrews, 1990; Andrews, 1995; Thompson et al., 2011). Rounding was qualitatively 
ANATOMICAL ELEMENTS
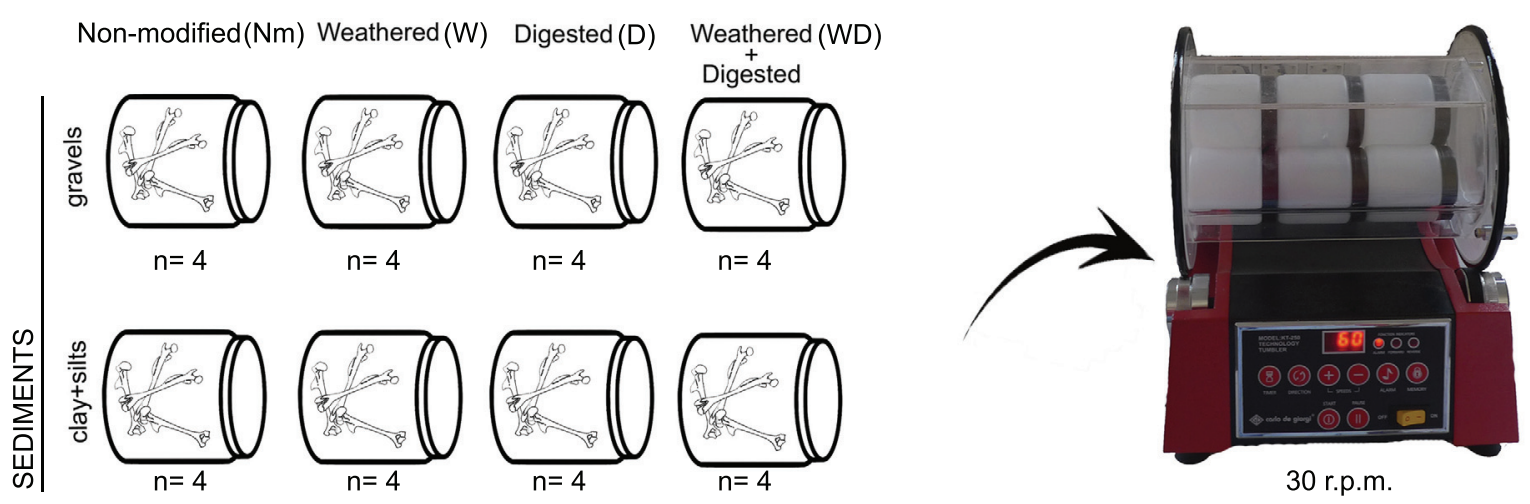

FIGURE 1. A container for each type of taphonomic modification was used (four containers for gravels and four for clay + silts) and four skeletal elements for each container were introduced. The eight containers were introduced in a stone polishing tumbler with a constant speed of 30 revolutions per minute (r.p.m.).

evaluated by Fernández-Jalvo and Andrews (2003) based on comparative criteria establishing different degrees. In order to prevent subjective appreciations, the loss of bone surface that rounding produces can be quantitatively evaluated applying mathematical and statistical models. A preliminary, simple and easy methodology is here developed using the function 'Analysis' from the software Adobe Photoshop CS6. This function calculates the number of pixels, which is present on an image previously selected with the 'Quick selection tool'. The function includes an option to apply the corresponding factor scale (converting automatically pixels to $\mathrm{mm}^{2}$ ) in case the different images do not have the same scale bar. Finally, the

$$
\text { Surface loss }=1-\left(\frac{S_{360 h}}{S_{0 h}}\right)
$$

surface abraded was calculated following the formula:

Where $S_{O h}$ is the 2D surface outline measured at the initial stage of the experiment and $S_{360 h}$ is the 2D surface outline measured at the end of the experiment (Figure 2). For each taphonomic alteration category, mean values of surface loss were calculated. The index gives an approximate value of surface loss (a percentage of pixels lost from one image to another) in a 2D perspective provided by photographs with a good depth of field thanks to a motorized zoom focus that provides well focused images in depth.

Differences between the percentages of surface loss obtained for each category of taphonomic modifications in gravels and clay + silts were anal- ysed applying a Generalized Linear Model (GLM) using $\mathrm{R}$ (R Core Team, 2019) with a quasibinomial error distribution and a confidence interval of $95 \%$. As the data analysed are considered non-parametric (they follow a non-normal distribution), the model transforms them obtaining a normal distribution and adjust the data as it was a linear regression. This model makes possible to show the results in an ANOVA table applying a Chi-square test to simplify and better understand the results. The amount of variance explained by the model

$$
D_{2}=\frac{\text { Null deviance-Residual deviance }}{\text { Null deviance }} * 100
$$

can be calculated through the $D^{2}$ parameter, following the formula:

This parameter returns a percentage, which in this case is explaining how much of the variance detected by the model is related with the initial state of modification present on the remains selected.

We have found serious difficulties in obtaining an homogeneous experimental sample with similar shape and size long bones (i.e., complete bearing the ends fused) for each of the different categories of bone type (i.e., non-modified, digested, weathered, fossils). This has influenced a relative small sample size but enough to apply simple non-parametrical statistical analyses. Observational and statistical results have been valuable to show a trend and identifiable criteria to identify the effects of abrasion. 


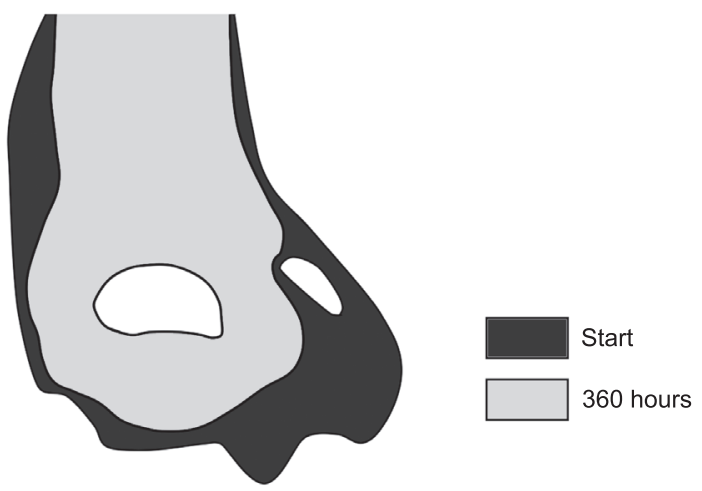

FIGURE 2. Graphic representation for the surface loss measurements. The index is calculated measuring the bone at the initial stage (black shade) and dividing the result with the measurement done at the final stage (light grey figure). The result is subtracted from 1 and then multiplied by 100 , obtaining a percentage indicating the surface loss between the initial and the final

\section{RESULTS}

\section{Modifications Produced by Gravels Sediment Size and Water}

Main modification caused by gravels and water consists of rounding (flattening bone protuberances) and polishing (surface brightness). All bones previously affected by taphonomic modifications have shown changes. After 24 hours, minor modifications were observed, but the effects of abrasion become more evident after 72 hours and increased progressively along the experiment. Non-modified and digested elements were the least affected specimens by abrasion process, followed by weathered and weathered + digested elements (Table 2 and Figure 3). Weathering causes cracks and splits on the bone surface. Our specimens did only reach stage 1-2 according to Andrews (1990), and at the end of our experiment signs of weathering (e.g., slight splitting) disappeared.

Fossil bones were the most abraded. Digested fossil remains tend to lose the original shape after 360 hours (e.g., femora, Figure 4). In spite of the relatively light grades of digestion obtained in our experimental specimens, digestion appears to increase the effects of abrasion (surface bone loss) in each of the categories here considered (Figure 3).

Apart from rounding and polishing, exposure of cancellous tissues was observed on articular surfaces of non-modified and weathered humeri and femur heads (Figure 5). Exposure of cancellous tissue on epiphyses mimics digestion and was
TABLE 2. Mean values of surface loss (in \%) calculated for all the bones included in each category of taphonomic modification, in modern and fossil bones, depending on the sediment in which they were abraded. Total mean was calculated for a better representation of the tendency showed by the data obtained. Values in bold correspond to skeletal elements broken during the experiment.

\begin{tabular}{|c|c|c|}
\hline & Gravels & Clay + silts \\
\hline \multirow[t]{5}{*}{ Non-modified } & $10.74 \%$ & $1.30 \%$ \\
\hline & $14.59 \%$ & $0.34 \%$ \\
\hline & $4.74 \%$ & $2.74 \%$ \\
\hline & $5.97 \%$ & $0.50 \%$ \\
\hline & $\begin{array}{c}\text { TOTAL MEAN } \\
9.01 \%\end{array}$ & $\begin{array}{c}\text { TOTAL MEAN } \\
1.22 \%\end{array}$ \\
\hline \multirow[t]{5}{*}{ Digested } & $17.80 \%$ & $1.88 \%$ \\
\hline & $14.97 \%$ & $4.53 \%$ \\
\hline & $6.55 \%$ & $4.98 \%$ \\
\hline & $1.70 \%$ & $1.53 \%$ \\
\hline & $\begin{array}{c}\text { TOTAL MEAN } \\
10.26 \%\end{array}$ & $\begin{array}{c}\text { TOTAL MEAN } \\
3.23 \%\end{array}$ \\
\hline \multirow[t]{5}{*}{ Weathered } & $28.92 \%$ & $6.67 \%$ \\
\hline & $17.24 \%$ & $7.77 \%$ \\
\hline & $17.56 \%$ & $0.79 \%$ \\
\hline & $10.59 \%$ & $0.50 \%$ \\
\hline & $\begin{array}{c}\text { TOTAL MEAN } \\
18.57 \%\end{array}$ & $\begin{array}{c}\text { TOTAL MEAN } \\
3.93 \%\end{array}$ \\
\hline \multirow{5}{*}{$\begin{array}{l}\text { Weathered + } \\
\text { digested }\end{array}$} & $26.19 \%$ & $5.07 \%$ \\
\hline & $16.57 \%$ & $3.36 \%$ \\
\hline & $32.93 \%$ & $2.29 \%$ \\
\hline & $31.18 \%$ & $0.00 \%$ \\
\hline & $\begin{array}{c}\text { TOTAL MEAN } \\
26.72 \%\end{array}$ & $\begin{array}{c}\text { TOTAL MEAN } \\
2.68 \%\end{array}$ \\
\hline \multirow{3}{*}{$\begin{array}{l}\text { Non-digested } \\
\text { fossil }\end{array}$} & $14.17 \%$ & $2.49 \%$ \\
\hline & $33.23 \%$ & $3.33 \%$ \\
\hline & $\begin{array}{c}\text { TOTAL MEAN } \\
23.70 \%\end{array}$ & $\begin{array}{c}\text { TOTAL MEAN } \\
2.91 \%\end{array}$ \\
\hline \multirow[t]{3}{*}{ Digested fossil } & $18.18 \%$ & $13.85 \%$ \\
\hline & $35.42 \%$ & $1.01 \%$ \\
\hline & $\begin{array}{c}\text { TOTAL MEAN } \\
26.80 \%\end{array}$ & $\begin{array}{c}\text { TOTAL MEAN } \\
7.43 \%\end{array}$ \\
\hline
\end{tabular}




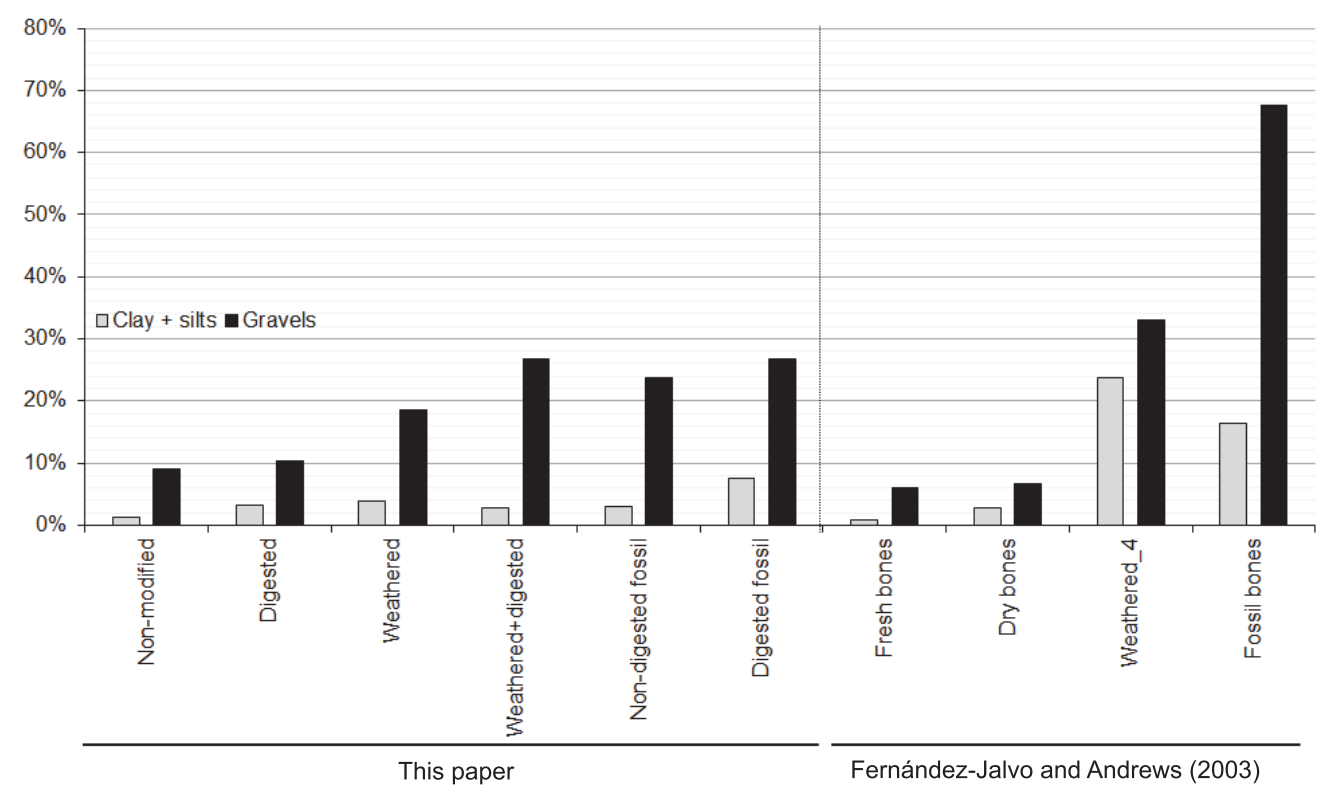

FIGURE 3. Total mean values of surface loss obtained for the skeletal elements included in each taphonomic category and sediment. In general terms, modifications present on elements introduced in clay + silts are the result of the breakage of the elements. Large mammal fragments studied in Fernández-Jalvo and Andrews (2003) with pictures before and after the experiment have also been included here to compare to our results, although this is only based on one specimen

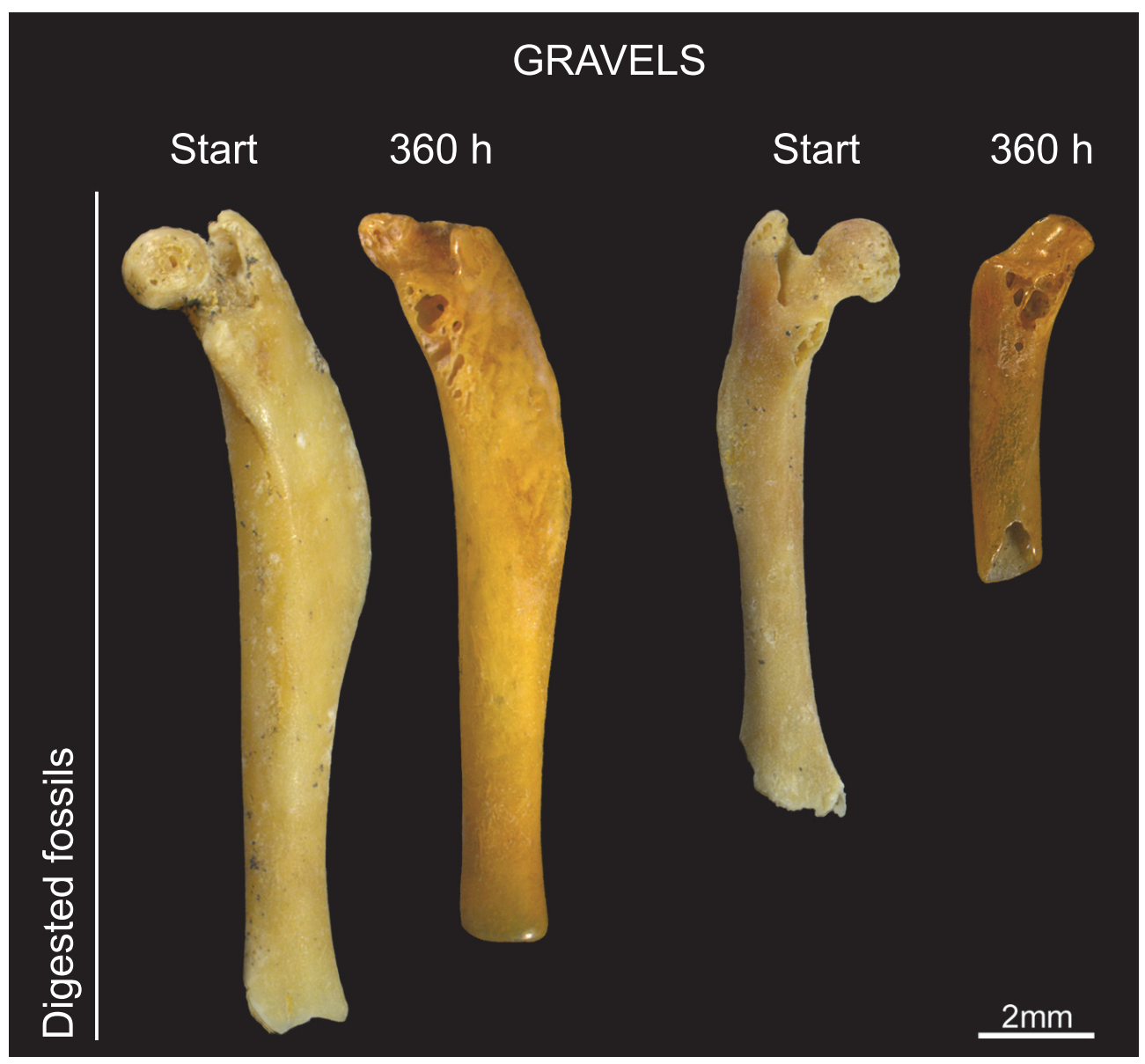

FIGURE 4. Digested fossil femora abraded with gravels after 360 hours. 

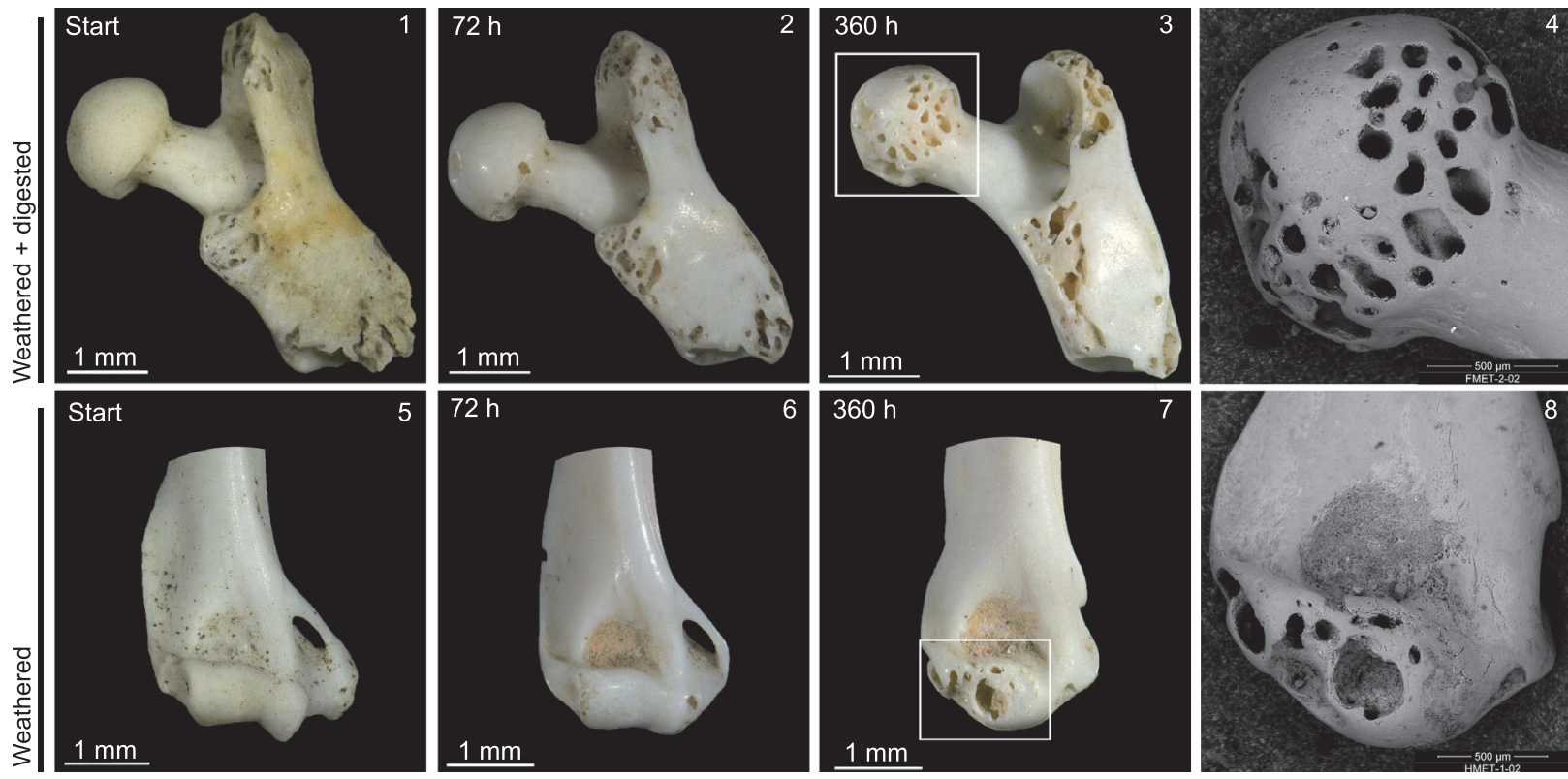

FIGURE 5. 1 to 4: weathered + digested femur at different stages of abrasion. Note that this proximal end of femur was selected because the head of the femur (fused and intact), in contrast to the trochanters with cancellous tissues exposed that indicate digestion. The shaft was broken before digestion. After 72 hours (2) cancellous tissues appears at the base of the head articulation, and after 360 hours (3) cancellous tissue is exposed on the articular head of the femur (4). This trait mimics the effects caused by digestion process, seen in detail in 4 SEM microphotograph of the same specimen; 5 to $\mathbf{8}$ : same traits observed on (non-modified) weathered distal humerus.

present on both modern and fossil bones after our abrasion experiment, greatly noticeable after 360 hours (Figure 5).

Comparing pictures before and after the experiment from Fernández-Jalvo and Andrews (2003) allowed us to calculate the surface loss to roughly compare our experiment with abraded large mammal bone fragments (Figure 3). We should, however, be cautious as the large mammal sample from Fernández-Jalvo and Andrews (2003) is based on only one specimen photographed.

\section{Modifications Produced by Clay + Silts Sediment Size and Water}

Results obtained from bones abraded by clay + silts sediment size and water do not show significant changes on salient angles or surface loss. The same results were obtained for fossil bones (Table 2).

Taphonomic modifications, such as weathering (cracks and splitting) or digestion (irregular corroded surfaces or cancellous tissues exposed), persisted all along the experiment of abrasion with clay and silts. Some bones incidentally broke and fracture edges were then slightly rounded (Figure 6 ), but modifications produced by this type of sediment were not easily observed, even at the final stage of the experiment (360 hours). These results are supported by the low surface loss values obtained. Excluding those values related to broken skeletal elements at the end of the experiment, percentages of surface loss are not above $5 \%$ (Table 2).

\section{Statistical Analyses}

Results obtained for the statistical analysis are shown in Tables 2 and 3. Significant differences were present for gravels ( $p$-value $=7.773 \mathrm{e}^{-}$ 5 ) between the proportion of surface loss and the different taphonomic modification categories. The percentage of variability explained by the model was $28.5 \%$, and the coefficient obtained corroborates that the surface loss increased from nonmodified to weathered + digested elements and fossil non-digested and digested remains. The statistical analysis for clay + silts sediment size shows no significant differences between the values of surface loss obtained between initial and final stages of all taphonomic modification here considered $(p$-value $=0.101)$. In this case, the variability explained by the model calculated between the different taphonomic modifications was low (8.6\%) and also no significant, which can be observed on the graphics obtained from the GLM (Figure 7). 


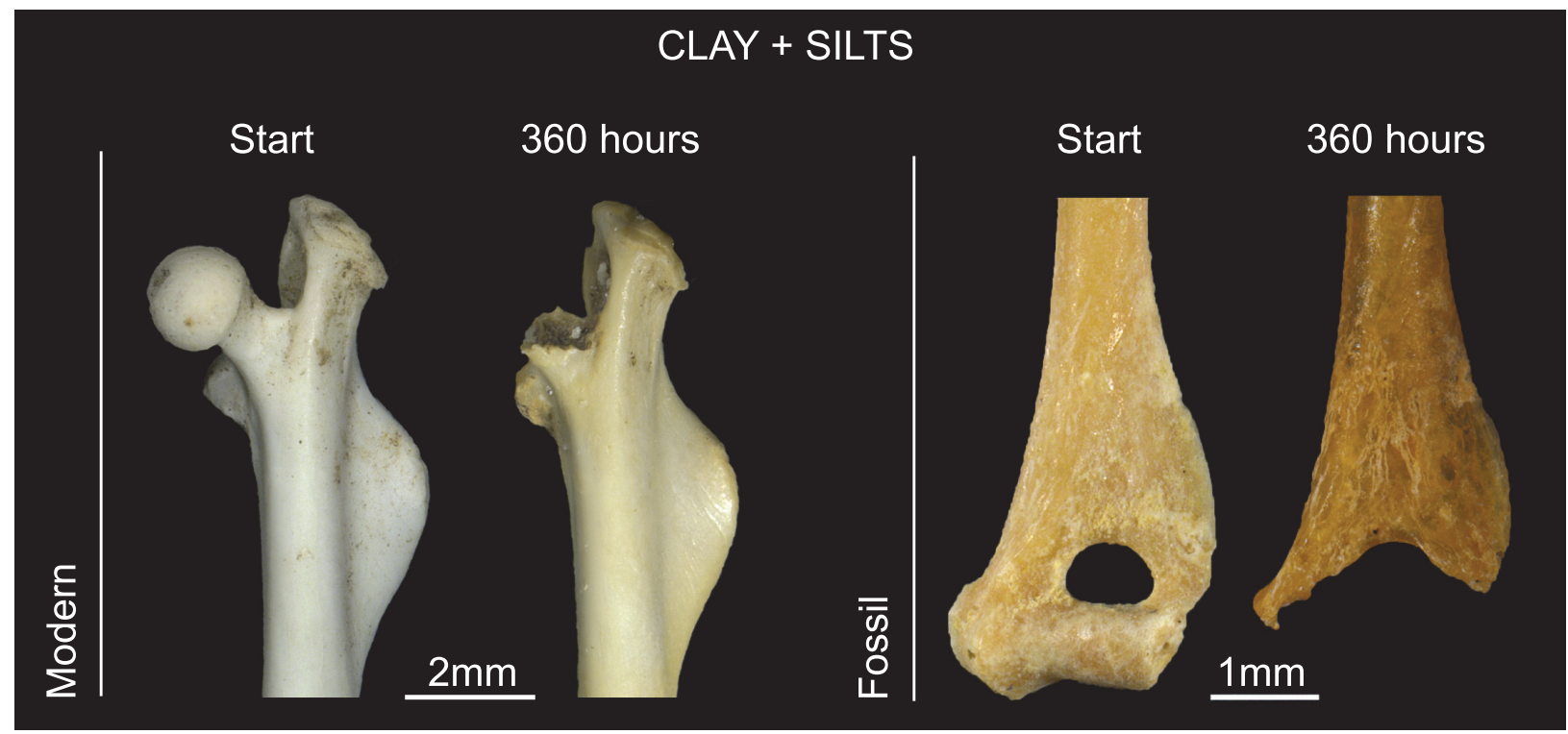

FIGURE 6. Modern femur and fossil humerus abraded with clay + silts. They were found broken at the end of the experiment and edges were slightly rounded.

\section{DISCUSSION}

Water transport is characterized by a mix of bone degradation with rounding and polishing, which do not imply a degradation of bone structure (Andrews and Fernández-Jalvo, 2016). For the first time we tested the effects of water abrasion on small mammal bones previously affected by different taphonomic modifications, and attempted to quantify the effects of bone loss caused by rounding and polishing in an experimental way.

Abrasion as a consequence of water transport on small mammals have been less studied than for large mammal remains, because they are easily displaced under low water streams $(<0.35 \mathrm{~m} / \mathrm{s}$, Dodson, 1973). Many situations may cause transport of such small sized bone elements, not always floating in water, but dragged together with the sediment. Even more critical is the case of fossils highly mineralized, cemented or attached to the sediment that may be transported for long time and long distances from the original location. In this respect, abrasion affecting fossils have been mentioned by other authors, such as Laudet et al.
(1997) and Tomassini and Montalvo (2013) indicating that abrasion is plausible for small sized bone elements. We, however, should keep in mind that rounding effects can also be the result of digestion processes, which has a special role on small mammal assemblages.

Analysis of digestion on both cranial and postcranial skeletons of small mammal assemblages is the most useful trait to recognise the presence of predation and identify the predator involved in fossil assemblages (Andrews, 1990). When abrasion is unnoticed, transport and reworking may not be identified, and abrasion may distort the original traits of digestion. Both aspects lead to incorrect palaeoenvironmental and chrono-biostratigraphical interpretations (e.g., Efremov, 1940; Behrensmeyer, 1988; Behrensmeyer and Kidwell 1985; Fernández-López, 1991).

Our results show that abrasion by clay + silts in water cause mild or absent bone rounding and polishing in agreement with previous experiments carried out by Fernández-Jalvo and Andrews (2003) and Fernández-Jalvo et al. (2014). The for-

TABLE 3. Results from the statistical test applied and the estimate coefficient for the response variable applying the Generalized Linear Model (GLM). The D2 indicates how much variability is explained by the initial taphonomic modification affecting the bone surface. Analyses were done with a $95 \%$ of confidence interval.

\begin{tabular}{lccccc}
\hline & $\mathbf{D}^{\mathbf{2}}$ & $\begin{array}{c}\text { Degrees of } \\
\text { freedom }\end{array}$ & p-value & Coefficient & Standard error \\
\hline Gravels & 0.285 & 38 & $7.773 \mathrm{e}-5$ & 0.288 & 0.074 \\
Clay + silts & 0.086 & 33 & 0.101 & 0.225 & 0.136 \\
\hline
\end{tabular}



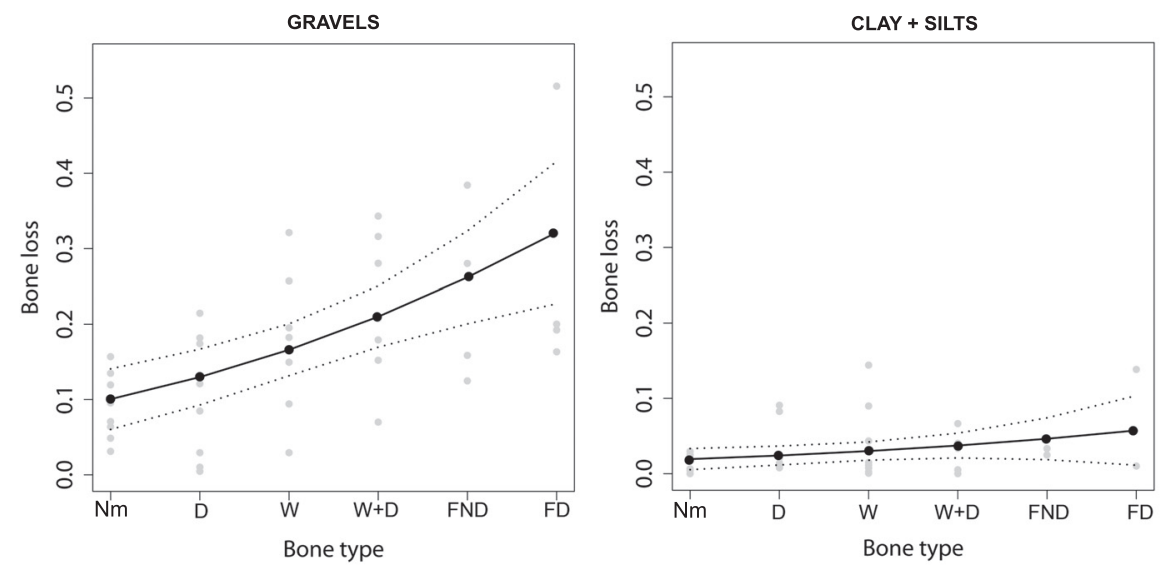

FIGURE 7. Graphic representation of the Generalized Linear Model (GLM) comparing surface loss between the different initial taphonomic stages. Both graphics show an increasing tendency from the first bone type (Nm) to the last (FD). This tendency is significant and more pronounced for gravels, while in clay + silts is practically horizontal. Nm: non-modified; D: digested; W: weathered; W+D: weathered + digested; FND: fossil non-digested; FD: fossil digested.

mer publication demonstrated that this fine sediment produces almost no modifications on small mammal long bones, except in certain skeletal elements that are difficult to be preserved complete (i.e., scapulae); although all bones obtained a matte surface. This trait was also observed by Fernández-Jalvo et al. (2014) on bones exposed to grain sizes equal or smaller than fine sands $(<250$ $\mu \mathrm{m})$ with small mammal remains from owl pellets with no sign of corrosion by digestion.

Fernández-Jalvo and Andrews (2003) also experimented with large mammal bone fragments and observed rounding on both weathered and fossil 'large mammal' bone fragments abraded by fine sediment in contrast to fresh and dry bones (Figure 3 ). Our results, however, show a mild rounding in all types of bones and bone surface remains almost as originally (Figure 3 ). In fact, the statistical analysis showed that the taphonomic modifications affecting the bones from our experiments have not greatly influenced the values of surface loss calculated (see Table 3). In light of the results obtained in this experiment, we can corroborate that the slight rounding observed in PRERESA site (García-Morato et al., 2018) is the consequence of a mild grade of digestion instead of abrasion produced by this sediment size.

Water with gravels have caused intense rounding and a bright surface affecting in different intensity fresh, dry, weathered, digested or fossil bones, both large and small mammals. The percentages of surface loss calculated in Table 3 show statistical significant differences, partially influenced by the initial taphonomic modification that previously affected bones (see Table 3). The total percentage of the variance explained by the initial taphonomic modification was $28 \%$, which indicates that other factors are influencing these values such as sediment grain size, time of exposure and even the velocity of the water flow (Dodson, 1973; Korth, 1979; Fernández-Jalvo and Andrews, 2003; Fernández-Jalvo et al., 2014).

Non-modified and digested modern elements showed similar values at the end of the experiment (9 and 10\%, respectively) (Table 2 and Figure 3 ) slightly higher in digested bones. This is more noticeable on digested + weathered bones and digested + fossils. In this paper, most of the elements selected as digested showed a light degree, both in genet or felid prey assemblages, as well as the fossil assemblage produced by hyenas (Williams et al., 2018). Figure 3 shows that in spite of this mild grade of digestion, those specimens affected by digestion increase the effects of abrasion (Table 3 ) especially in weathered and fossils. Likely, the greater the degree of digestion, the greater are the abrasion effects.

Percentages of surface loss from weathered and weathered + digested elements were different between them and from non-modified and digested elements and showed higher percentages of surface loss (Figure 3). Weathering was not very intense on the bones selected for this work (stage 2 ). At the end of the present experiment, any signal of weathering was removed on bones immersed in gravels. However, Fernández-Jalvo and Andrews (2003) indicated that weathered bones reaching categories 3-5 bear cracks, splits and exfoliation 
on surface and the splitting induced penetrates deeper into the bone (Behrensmeyer, 1978) and even after abrasion, the effects of weathering can still be recognized. Likely, it may be expected that the greater the stage of weathering, the greater the abrasion effects.

Fossil bones were the most intensively affected by abrasion. Final experiments show greater surface loss in fossils $(23.7 \%)$ than in modern weathered $(18.57 \%)$ or non-modified bones (9\%). These results corroborate previous observations done by Fernández-Jalvo and Andrews (2003) on large mammal fossil bone fragments and by Fernández-Jalvo et al. (2014) on fossil small mammal remains from Olduvai Gorge. Here we introduced new variable, digested fossils, which showed an intense rounding producing a loss of the shape in some of the specimens (Figure 4). For instance, Laudet et al. (1997) show small mammal postcranial elements from Pech Crabit (France), and some of them are extremely rounded by transport and abrasion. According to results obtained in our experiments, we may support that transport most likely occurred as result of reworking when skeletal elements were already fossilized and transported by coarse sediments, see figure 7 from Laudet et al. (1997).

Apart from rounding and polishing, exposure of cancellous tissues was observed in non-modi- fied, weathered and fossil specimens. This trait was also detected by Fernández-Jalvo et al. (2014) on the non-modified small mammal remains but not in fossil remains. These authors proposed that the absence of cancellous tissues exposed could be a distinct trait to recognise whether bones were transported as fossils or while they were still fresh. As Fernández-Jalvo et al. (2014) indicated, we agree that further experiments on abrasion with fossil bones need to be conducted. So far, our results (Figure 8) indicate that exposure of cancellous tissues can also occur on fossil femora and humeri, so this trait is not useful to recognise whether the bones were fresh or fossil when they were abraded.

Exposure of cancellous tissues by water abrasion can mimic the effects of digestion. Bones start showing the effects of digestion on the epiphyses, and corrosion extends towards the diaphysis once entry has been gained through the ends of the bones (Andrews, 1990). Postcranial digestion at light degrees affects the epiphyses, but at higher degrees the articular ends are corroded as well as the metaphyses and the shaft (Figure 9.1). The presence of digestive corrosion in shafts should be observed to reinforce the differences between abrasion and digestion.

Acid juices of the stomach corrode bone edges that become thinner (Raczynski and

\section{NON-DIGESTED FOSSIL}
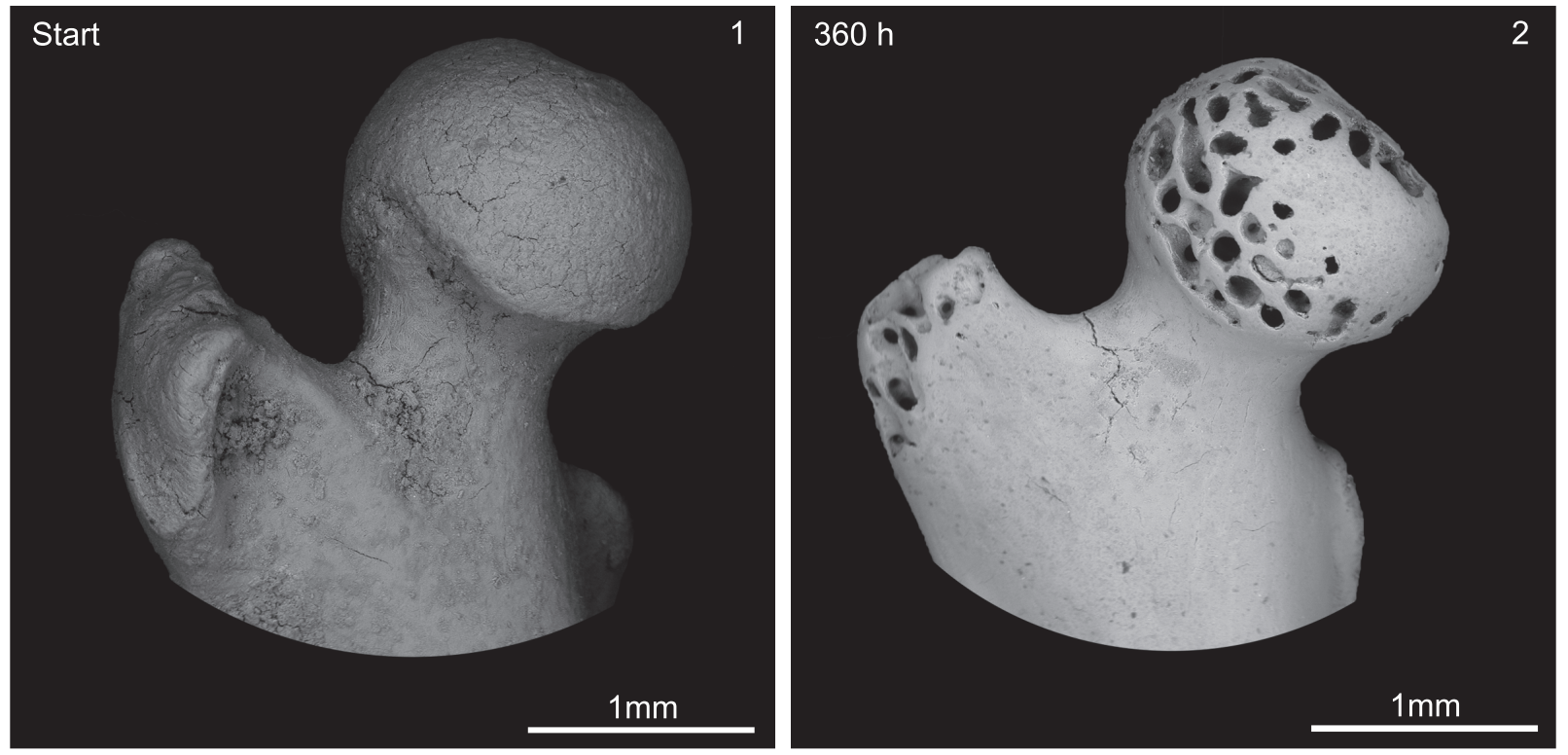

FIGURE 8. 1. SEM microphotographs of non-digested fossil femur before the experiemnt started; 2 . The same specimen after 360 hours immersed in water and gravels 


\section{Modern bones}

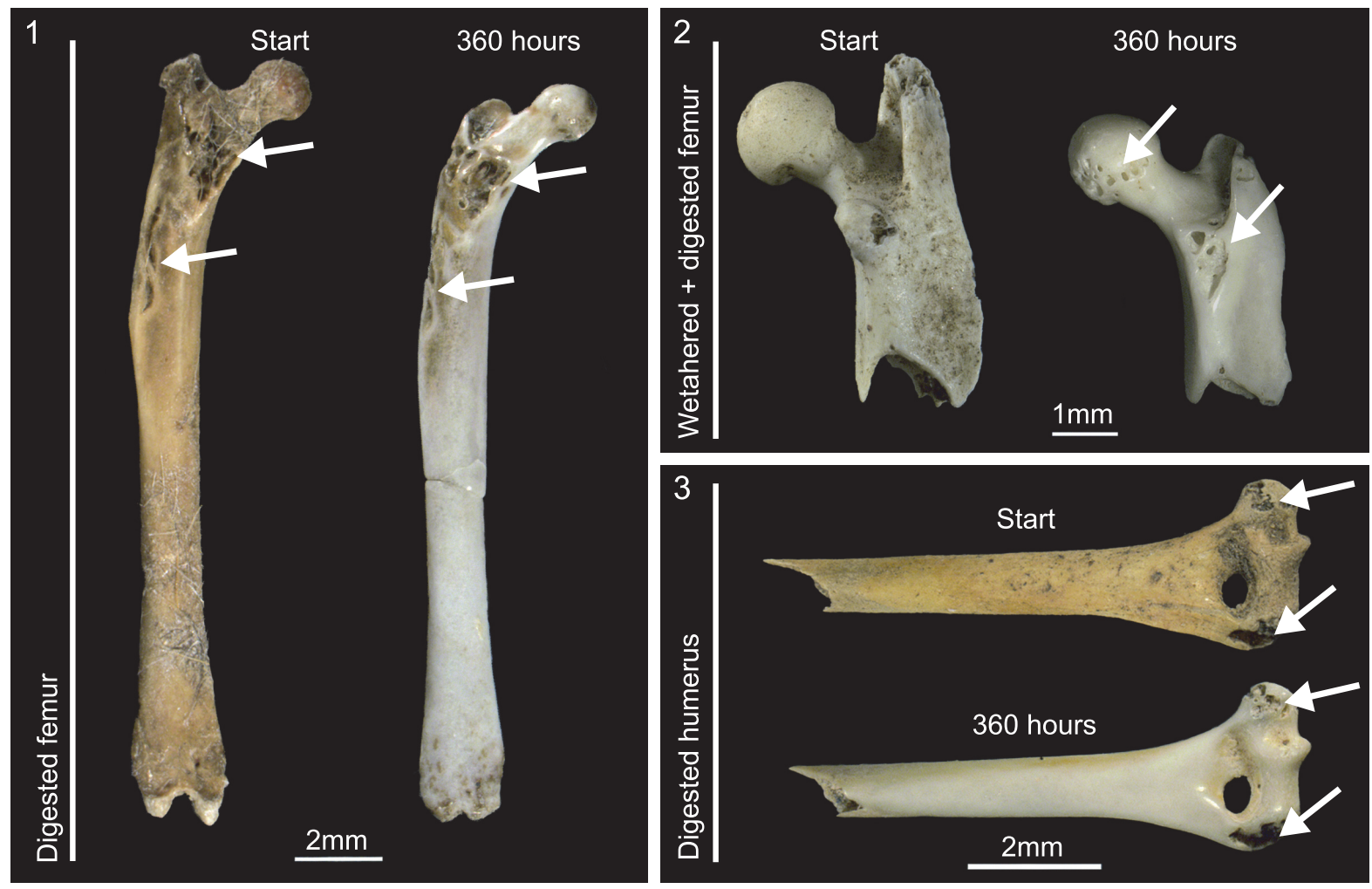

Fossil bones
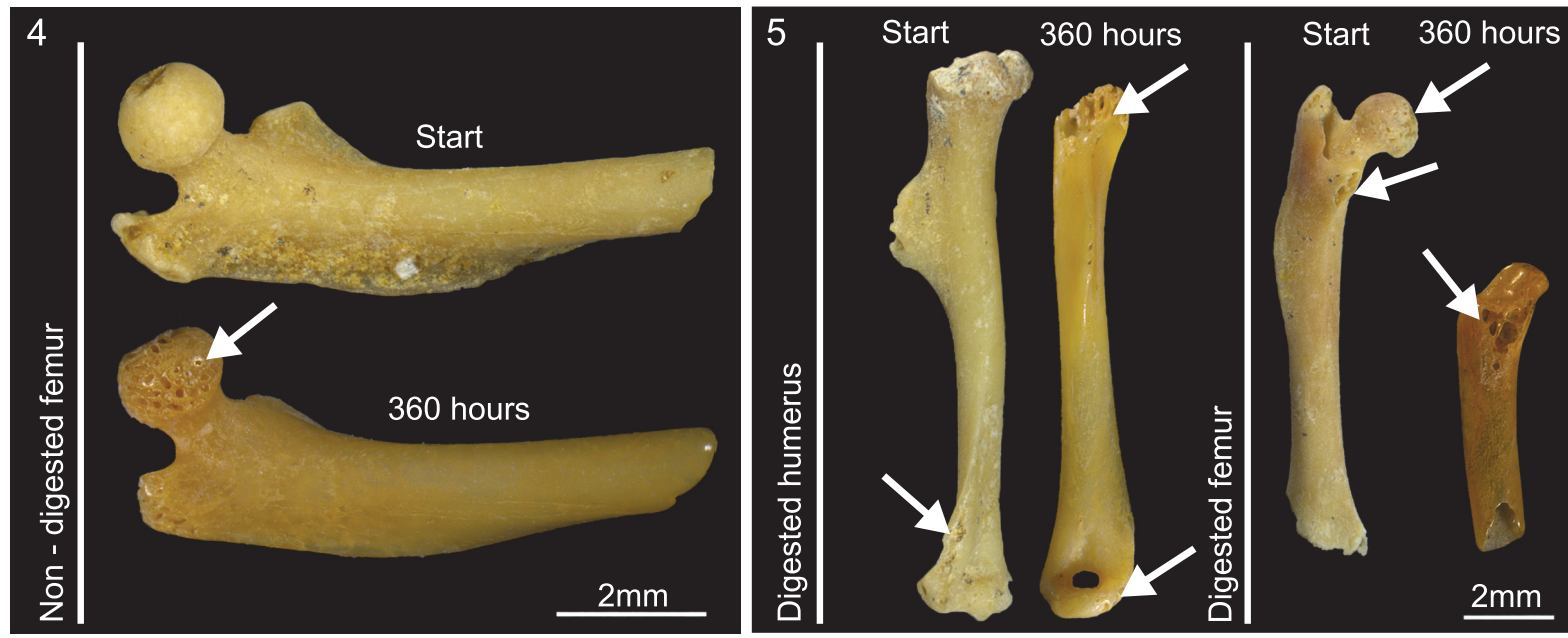

FIGURE 9. 1. Femur initially digested. Corrosion produced by digestion penetrates the diaphysis of the bone and persists up to 360 hours of experiment, and abrasion cannot reproduce this trait; 2 . Femur initially weathered shows cancellous tissues exposed mimicking digestion, and cracks and splits erased; 3 . Weathered + digested humerus show mild digestion on the distal part, and after 360 hours the effects of mild digestion are similar to the effects produced by abrasion, although the intense rounding; 4. Non-digested fossil femur. After 360 hours cancellous tissues are exposed mimicking digestion damage as it was observed for modern bones; 5. Previously digested femur and humeri, digestion can be identified after abrasion on the trochanter of the femur and on distal and proximal ends of the humeri. 

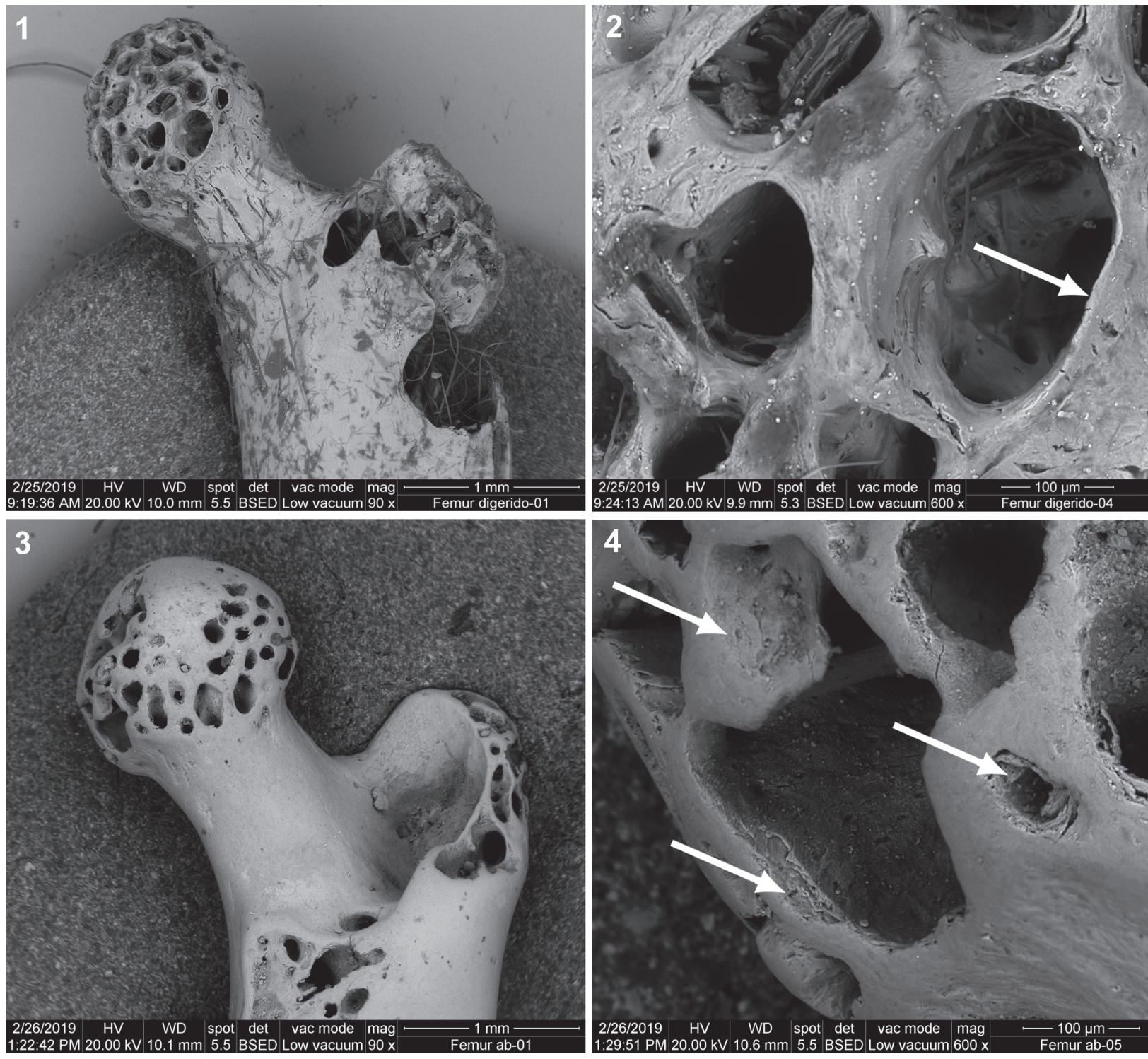

FIGURE 10. 1. SEM microphotograph of a femur showing digestion; 2. Detail of cancellous tissue exposed. The edge of the walls are thinned by digestion (white arrow); 3. SEM microphotograph of a femur affected by abrasion; 4 . Detail of cancellous tissue showing the edge of the walls homogeneously rounded by abrasion and borders broken (white arrows).

Ruprecht, 1974; Mellet, 1974; Mayhew, 1977; Andrews, 1990). This reinforces differences between digestion and abrasion. In case that small mammal bones have been abraded, and the cancellous tissues are exposed on the articular ends, another criteria to distinguish between digestion and abrasion is to observe the edge of the exposed cancellous tissues at high magnifications (Figure 10). When bones are affected by digestion the edge of the cancellous tissue appears thinner (Figure 10.2), while if damaged by abrasion the edge is thick and homogeneously rounded (Figure 10.4).
Light digestion may be unnoticed (Figure 9.3) or appear more intense after abrasion (Figure 9.4). In these cases, the overall aspect of salient angles and rounded broken edges may warn on the influence of abrasion. Furthermore, teeth (and other skeletal elements) may support either strong digestion and/or abrasion effects on postcrania. Comparison of abrasion on bones bearing different grades of digestion is an aspect that requires further work. Similarly, experiments with a larger sample size will corroborate the results obtained in this paper and increase the understanding of other fac- 
tors that may influence, reduce and increase the effects of bone abrasion.

\section{CONCLUSION}

1. Results obtained for abrasion produced by fine sediments (clay + silts) and coarse gravels agrees with most observations obtained by other authors in previous works. We have increased results referred to small mammal long bone abrasion with different types of bones (weathered, digested, fossils) to distinguish abrasion vs. digestion in postcrania.

2. Positive results were obtained applying a new methodology to measure the effects of rounding on bones based on quantitative data (surface loss) and give us the possibility to reinforce the observations based on qualitative criteria. Moreover, the application of software of image analysis can be a useful tool to control, which parameters have major influence on abrasion processes, as the data obtained can be statically analysed and mathematically modelled.

3. For the first time, abrasion has been tested on small mammal bones with different initial taphonomic modifications, including digested elements. Digestion has been observed to increase the effects of abrasion.

4. Rounding and polishing or the presence of matt surfaces was almost not detected on those elements immersed in water and abraded with clay + silts and did not have any relevance on the surface loss values obtained. This is in contrast to previous experiments with large mammal fragment bones that did show water abrasion by clay + silt on fossils and weathered bones. These results warn that abrasion produced by fine clayish type of sediments may not be recognized in fossil assemblages.

5. The effects of abrasion are more conspicuous when bones are immersed in water with gravels. Weathered and fossils (either digested or not) are the most affected by abrasion. Cracks and splits caused by low stages of weathering are obliterated by abrasion, but digestion traits persist (such as holes due to collapse of cortical tissues whose edges are thinned by digestion or just rounded by abrasion) and can be recognized in some elements even after intense abrasion.
6. Although the initial stage of the bone on fossil assemblages cannot be known, an estimation of unmodified complete bone shape can be compared to rounded bones and calculate an approximate rate of rounding. The state of the bone may explain mixtures in a fossil site and recognize evidences of reworking.

7. Proximal femora and distal humeri showed exposure of cancellous tissues by abrasion on non-modified and weathered elements. This trait was previously observed on abraded modern bones from Tyto alba but not in abraded fossils. Results of our study showed that cancellous tissues can also be exposed in fossil bones contrary to observations previously described elsewhere.

8. The exposure of cancellous tissues when abrasion is involved mimics the effects of digestion and consequently, modifications produced by digestion can be obliterated on abraded fossil assemblages. In this situation, digestion cannot be evaluated on postcranial elements. Nonetheless, at SEM magnifications, the edge of the cancellous will show differences if digested (thinned) or abraded (homogeneously rounded).

9. Further studies are needed including a larger sample size and higher grades of both, digestion and weathering as well as other taphonomic modifications not considered here. The understanding of how abrasion can affect fossil small mammal assemblages and which parameters have a stronger influence may greatly help to better recognize reworking or resedimentation and reconstruct the original fossil assemblage.

\section{ACKNOWLEDGEMENTS}

This paper was funded by the project CGL2016-79334P of the Spanish Ministry of Research. SGM has a predoctoral grant from the Complutense University of Madrid (CT42/18-CT43/ 18). The authors are grateful to the professional work of the Electron Microscopy Unit technicians of the Laboratorio de Técnicas No Destructivas of Museo Nacional de Ciencias Naturales (CSIC). Thanks are also extended to the editor and anonymous reviewers whose comments and suggestions have greatly improved this paper. 


\section{REFERENCES}

Andrews, P. 1990. Ow/s, Caves and Fossils. British Museum (Natural History), London, and University of Chicago Press, Chicago.

Andrews, P. 1995. Experiments in taphonomy. Journal of Archaeological Science, 22:147-153. https://doi.org/10.1006/jasc.1995.0016

Andrews, P. and Ersoy, A. 1990. Taphonomy of the Miocene bone accumulation at Paslar, Turkey. Journal of Human Evolution, 19:379-396. https://doi.org/10.1016/00472484(90)90051-c

Andrews, P. and Evans, E.M. 1983. Small mammal bone accumulations produced by mammalian carnivores. Paleobiology, 9(3):289-307. https://doi.org/10.1017/ S0094837300007703

Andrews, P. and O'Brien, E.M. 2000. Climate, vegetation, and predictable gradients in mammal species richness in southern Africa. Journal of Zoology, 251:205-231. https:// doi.org/10.1017/s0952836900006075

Andrews, P. and O'Brien, E. 2010. Mammal species richness in Africa, p. 929-947. In Werdelin, L., Sanders, W. (eds.), Cenozoic Mammals of Africa. Columbia University Press, New York.

Behrensmeyer, A.K. 1975. The taphonomy and paleoecology of Plio-Pleistocene vertebrate assemblages east of Lake Rudolf, Kenya. Bulletin of the Museum of Comparative Zoology, 146:473-557.

Behrensmeyer, A.K. 1978. Taphonomic and ecologic information on bone weathering. Paleobiology, 4:150-162. https://doi.org/10.1017/S0094837300005820

Behrensmeyer, A.K. 1988. Vertebrate preservation in fluvial channels. Palaeogeography, Palaeoclimatology, Palaeoecology, 63:183-199. https://doi.org/10.1016/00310182(88)90096-X

Behrensmeyer, A.K. and Kidwell, S.M. 1985. Taphonomy's contributions to paleobiology. Paleobiology, 11:105-119. https://doi.org/10.1017/S009483730001143X

Dodson, P. 1973. The significance of small bones in paleoecological interpretation. Contributions to Geology, University of Wyoming Special Paper, 12:15-19.

Evans, T. 2014. Fluvial taphonomy, p. 115-141. In Pokines, J. and Symes, S.A. (eds.), Manual of Forensic Taphonomy. CRC Press, Boca Raton, Florida.

Fernandez-Jalvo, Y. 1995. Small mammal taphonomy at la Trinchera de Atapuerca (Burgos, Spain). A remarkable example of taphonomic criteria used for stratigraphic correlations and palaeoenvironmental interpretations. Palaeogeography, Palaeoclimatology and Palaeoecology, 114:167-195. https://doi.org/10.1016/0031-0182(94)00081-i

Fernández-Jalvo, Y. and Andrews, P. 1992. Small mammal taphonomy of Gran Dolina, Atapuerca (Burgos), Spain. Journal of Archaeological Science, 19(4):407-428. https://doi.org/ 10.1016/0305-4403(92)90058-B

Fernandez-Jalvo, Y. and Andrews, P. 2003. Experimental effects of water abrasion on bone fragments. Journal of Taphonomy, 3:147-163.

Fernández-Jalvo, Y. and Andrews, P. 2016. Atlas of Taphonomic Identifications: 1001+ Images of Fossil and Recent Mammal Bone Modification. Springer, Dordrecht. https://doi.org/ 10.1007/978-94-017-7432-1

Fernández-Jalvo, Y., Andrews, P., Denys, C., Sesé, C., Stoetzel, E., Marin-Monfort, D., and Pesquero, D. 2016. Taphonomy for taxonomists: Implications of predation in small mammal studies. Quaternary Science Reviews, 139:138-157. https://doi.org/10.1016/ j.quascirev.2016.03.016

Fernández-Jalvo, Y., Andrews, P., Sevilla, P., and Requejo, V. 2014. Digestion versus abrasion features in rodent bones. Lethaia, 47:323-336. https://doi.org/10.1111/let.12061

Fernández-Jalvo, Y. and Monfort, M.D.M. 2008. Experimental taphonomy in museums: Preparation protocols for skeletons and fossil vertebrates under the scanning electron microscopy. Geobios, 41:157-181. https://doi.org/10.1016/j.geobios.2006.06.006

Fernandez-López, S.R. 1984. Nuevas perspectivas de la tafonomía evolutiva: Tafosistemas y asociaciones conservadas. Estudios Geológicos, 40 :215-224.

Fernandez-López, S.R. 1985. Séquences sédimentaires et séquences taphonomiques. Strata, 2:116-122. 
Fernandez-López, S.R. 1991. Taphonomic concepts for a theoretical biochronology. Revista Española de Paleontología, 6:37-49.

Fernandez-López, S.R. 1995. Taphonomie et interprétation des paléoenvironnements. Geobios, 18:137-154. https://doi.org/10.1016/S0016-6995(95)80162-6

Fernández-López S.R. 2000. Temas de Tafonomía. Departamento de Paleonotología, Universidad Complutense de Madrid. 167 pp.

García-Morato, S., Sevilla, P., Panera, Joaquín., Rubio-Jara, S., Sesé, C., and Fernández-Jalvo, Y. 2018. Rodents, rabbits and pellets in a fluvial terrace (PRERESA site, Madrid, Spain). Quaternary International, available online. https://doi.org/10.1016/j.quaint.2018.04.012

Korth, W.W. 1979. Taphonomy of microvertebrate fossil assemblages. Annals of the Carnegie Museum, 48:235-285.

Laudet, F., Denys, C., and Fernandez-Jalvo, Y. 1997. Taphonomy of the Oligocene vertebrates from Pech Crabit (Southwestern France, Quercy Phosphorites): Geodynamical and paleoecological implications of the post-mortem reworkings. Geobios, 20:307-313. https:// doi.org/10.1016/s0016-6995(97)80036-8

Lloveras L., Moreno-García, M., Nadal, J., and Thomas, R. 2014. Blind test evaluation of accuracy in the identification and quantification of digestión corrosión damage on leporid bones. Quaternary International, 330:150-155. https://doi.org/10.1016/j.quaint.2013.07.033

Mayhew, D.F. 1977. Avian predators as accumulators of fossil mammal material. Boreas, 6:2531.

Mellet, J.S. 1974. Scatological origin of microvertebrate fossil accumulations. Science, 185(4148):349-350. https://doi.org/10.1126/science.185.4148.349

Piñeiro, A. and Barja, I. 2011. Trophic strategy of the wildcat Felis silvestris in relation to seasonal variation in the availability and vulnerability to capture of Apodemus mice. Mammalian Biology, 76(3):302-307. https://doi.org/10.1016/j.mambio.2011.01.008

R Core Team. 2019. R: A Language and Environment for Statistical Computing. R Foundation for Statistical Computing. Vienna, Austria. https://www.R-project.org/. (Accessed: 23/04/2019).

Raczynski, J. and Ruprecht, A.L. 1974. The effect of digestion on the osteological composition of owl pellets. Acta Ornithologica, 14:26-38.

Sesé, C. and Villa, P. 2008. Micromammals (rodents and insectivores) from the early Late Pleistocene cave site of Bois Roche (Charente, France): Systematics and paleoclimatology. Geobios, 41:399-414. https://doi.org/10.1016/j.geobios.2007.10.005

Stoetzel, E., Marion, L., Nespoulet, R., El Hajraoui, M.A., and Denys, C. 2011. Taphonomy and palaeoecology of the late Pleistocene to middle Holocene small mammal succession of El Harhoura 2 cave (Rabat-Tamara, Morocco). Journal of Human Evolution, 60:1-33. https:// doi.org/10.1016/j.jhevol.2010.07.016

Thompson, C.E.L., Ball, S., Thompson, T.J.U., and Gowland, R. 2011. The abrasion of modern and archaeological bones by mobile sediments: the importance of transport modes. Journal of Archaelogical Sciencie, 38:784-793. https://doi.org/10.1016/j.jas.2010.11.001

Tomassini, R.L. and Montalvo, C.I. 2013. Taphonomic modes on fluvial deposits of the Monte Hermoso Formation (early Pliocene), Buenos Aires province, Argentina. Palaeogegraphy, Palaeoclimatology, Palaeoecology, 369:282-294. https://doi.org/10.1016/ j.palaeo.2012.10.035

Voorhies, M.R. 1969. Taphonomy and population dynamics of an early Pliocene vertebrate fauna Knox County, Nebraska. Contributions to Geology, University of Wyoming Special Paper, 1:1-69.

Williams, J., Andrews, P., García-Morato, Sara., Villa, P., and Fernández-Jalvo, Y. 2018. Hyena as a predator of small mammals? Taphonomic analysis from the site of Bois Roche, France. Paleobiology, 44(3):511-529. https://doi.org/10.1017/pab.2018.13

Wolff, R.G. 1973. Hydrodynamic sorting and ecology of a Pleistocene mammalian assemblage from California (USA). Palaeogeography, Palaeoclimatology, Palaeoecology, 13:91-101. https://doi.org/10.1016/0031-0182(73)90038-2 